\title{
The Cultivation of Intercultural Communicative Competence in Senior High School English Teaching-Based on China's Standards of English Ability
}

\author{
Lingling Cai \\ Foreign Language Department, Sichuan University of Science and Engineering, China \\ Hong Yun \\ Foreign Language Department, Sichuan University of Science and Engineering, China
}

\begin{abstract}
Intercultural communicative competence is a prerequisite for students in senior high school to have a smooth communication with foreigners in the future. This paper discusses the current situation of students' ICC through questionnaires and then analyzes students' ICC problems respectively. In doing so, this paper offers some tentative teaching methods and hopes to cultivate students' intercultural communicative competence under the guidance of the China's Standards of English Ability.
\end{abstract}

Index Terms - intercultural communicative competence, high school teaching, the China's standards of English ability

\section{INTRODUCTION}

At present, China is a fast developing country in the world so that cultural exchanges are increasingly more frequent than before. Needless to say, China is in a bad need to enhance its citizens' English level to achieve successful intercultural communications because English is the very language used among different countries. As Alptekin (2002) mentioned the international communication in English "involves native-nonnative and nonnative-nonnative discourse participants ", it is widely admitted that intercultural communication is an important part of teaching English as a foreign language. Actually, from colleges to primary schools even some kindergartens, educational organizations spare no efforts to practice the English language teaching. However, the result of English teaching is far from satisfactions and cannot meet the real communicative need. Among many obvious problems, the biggest problem of English teaching lies in: cultural teaching is often ignored in the teaching process so that intercultural cultural competence of students is poorly developed. This is often a problem in the senior high school: most students who are good at exam grades still cannot communicate well with other people. What's worse, they even don't know the basic cultural facts of other counties and cultural perceptions as well as symbol systems during communicative process.

Luckily, many English experts have realized this problem and studied theoretical and practical aspects about intercultural communicative competence in colleges. Nevertheless, they are seldom aware of the intercultural communicative competence of senior high school students in that they believe that students should contribute much time and energy to learn English knowledge (such as vocabulary, sentence and passage) rather than cultural related knowledge and competence in senior high school. As a result, there are not many systematic studies on senior high school students' cultural awareness and intercultural communicative competence. In fact, except Teaching Syllabus for English Majors and College English Course Teaching Requirement, the Ministry of Education has promulgated culture sensitivity, cultural awareness and intercultural communicative competence as objectives in the New English Curriculum Standard (published in 2003). In 2011, the Curriculum raised this concept: students' cross-cultural communication awareness became a hot topic of English teaching, but senior high school English teaching still placed little importance on cultural teaching. Now that the newly issued China's Standards of English Language Ability (2018) once again proposed the requirement of cultural awareness and intercultural communicative competence in the English teaching process, it has already become an extremely urgent problem to seek the new and effective teaching methods.

As William Littlewood (1981) pointed that the primary goal of language teaching is to develop the ability to use the proper and real language to interact with others, one of the ultimate goal of English teaching in senior high school should help students to acquire the ability to perform a repertoire of intercultural acts. Therefore, the English teaching in senior high school needs to combine the knowledge of English and the communicative competence together. To sum up, this paper is firstly to interpret some key terms such as language and culture, cultural awareness and intercultural communicative competence; Then it will use some questionnaires to learn the current situation of senior high school students' intercultural communicative competence and discuss the underlying reasons; Lastly, this paper will propose 
some effective teaching methods based on the China's Standards of English Ability to cultivate students' intercultural communicative competence.

\section{LITERATURE REVIEW}

\section{A. Language and Culture (Their Relationship and Its Pedagogical Implication)}

Language is an integral part of culture and it is the carrier of culture. It is not exaggerating to say that most languages are constrained in culture and language could help to preserve a culture through its customs, beliefs and values, so the complicated relationship between them has become a major concern in linguistic field and teaching field especially in English teaching as a foreign language. According to Byram (1989), "language invariable refers to their knowledge and perception of the world, the concepts of culture, and cultural learning", that is to say, culture is the basic core of language learning and language teaching can hardly take place without implicitly teaching culture of language users. From the understanding of inextricable relationship between language and culture, it is obvious that the focus of English teaching should shift from the mere grammatical knowledge to cultural knowledge as well as communicative competence .In order to carry out a smooth intercultural communication, Chastain(1976), another famous linguist, clarifies this view that intercultural communication not only depends on language skills but also on the comprehension of cultural habits and expectations, so teachers in senior high school need to teach students what to say( or behave) and how to say( or behave) on different occasions to ensure that fewer problems will arise during the intercultural communication. What's more, language experts (such as Thomas) suggest that teachers should help students to attention to appropriateness in intercultural communication and develop a kind of intercultural awareness besides learning cultural facts.

\section{B. Intercultural Awareness (Its Pedagogical Implications)}

When it comes to the term intercultural awareness, it is necessary to learn the term "awareness". Freeman (1989) offered this definition:"Awareness is the capacity to recognize and monitor the attention one is giving or has given to something". Literally, awareness means a kind of ability of realizing something unknown before and being cognizant of something beneath the surface. When it refers to the cultural communication, it is not easy for nonnative speakers to realize the difference at a deep level. In this sense, language speakers need to form a cultural awareness (sensitivity) to the impact of culturally-induced behavior on language use and communication. For teachers, while teaching language, teachers also need help students to develop an ability to observe cultural difference and form a correct attitude to these differences. Furthermore, cultural awareness is correlated with both linguistic and non-linguistic dimensions of culture and it fosters the development of intercultural awareness. Different from cultural awareness, intercultural awareness attaches more importance to achieve multicultural mind-set, which includes both the native culture and target culture. The intercultural awareness prefers to deal with the relationship (interaction) between the two cultures compared with the cultural awareness whose focus is on the similarities and differences. According to Chen \& Starosta (1998) and Bennett (1993), intercultural awareness can be defined as "a positive drive to understand, appreciate and accommodate cultural differences and form an appropriate and effective behavior in intercultural communication", the intercultural awareness is not born with speakers but a developmental one which needs to be picked up during the teaching process. In addition, intercultural awareness mainly examines how people feel about and make sense of people who are culturally different, so the intercultural competence is an underlying factor which supports the intercultural competence and forms effective intercultural communication. Generally speaking, intercultural awareness can be analyzed from three aspects: affective aspects, behavioral aspects and cognitive aspects, which just corresponds to the same three aspects of intercultural competence. For pedagogical implications, teachers need to be clear about one fact that intercultural awareness is not simply based on culture learning and also needs to arouse learners' attitudes along with intentions to other cultures. In doing so, teachers need to develop learners' critical thinking and tolerance to other cultures.

\section{Intercultural Communicative Competence}

Scholars and educators all over the world have made lots of achievements on the study of intercultural communicative competence so far, but there is still no consensus on this topic. This paper will try to make a conclusion about the definition and analyze its dimensions on the basis of other famous scholars' studies.

1. Theoretical and Practical Studies of ICC Abroad

At first, intercultural communication research originated from Hall's masterpiece-- The Silent Language (1959) and since then intercultural communication study flourished in American land. In 60s and 70s of last century, more works about intercultural communicative competence appeared and some professional courses were opened in universities. It was worth mentioning that some books published in 1970s still had a significant influence on today's study, such as International Communication: A Reader (Larry Samovar\& Richard Porter, 1972). In 1980s, the study of intercultural communicative competence became more popular than before because many influential scholars joined in this research, so the intercultural communicative competence became an interdisciplinary study including different approaches. Since the 2000s, the study of intercultural communicative competence still continues to receive attentions from many scholars, but there is no agreement on the definition and framework of ICC. Albeit there are debates on it, intercultural 
communicative competence is simply described as the ability to communicate effectively and properly with people from diverse linguistic and cultural background. In recent researches, it is generally agreed that there are three core elements about it: affect, behavior and cognition or knowledge. Many scholars develop some models to cultivate the intercultural communicative competence among overseas students and gain some achievements. Even if it may not be fit for the reality in China, it still provides some useful hints for Chinese foreign language teaching.

2. Theoretical and Practical Studies of ICC in China

Compared with studies abroad, studies of intercultural communicative competence in China start late and are not as rich as studies abroad, but it is helpful for Chinese foreign language teaching. As early as 1980s, some educators had devoted to the research and pointed out that language learning was as important as culture learning and both of them should be written in teaching syllabus. Moreover, teachers need to be aware that cultural difference will influence the result of intercultural communication so that teachers need to develop the intercultural communicative competence in class. In the mid-1980s, some colleges began to offer some intercultural communication courses and did some researches among colleges. In 1988, Professor $\mathrm{Hu}$ Wenzhong published the first book about intercultural communication in domestic English teaching which opened the new path for studies of ICC in China. Later, a series of books written by $\mathrm{Hu}$ and his colleagues discussed about the cultural differences between Chinese and English in order to develop students' ICC in English class. Other Chinese scholars like Zhang Hongling (2007) also thought that ICC had three elements: attitude, knowledge and behavior, which corresponded to the terms abroad. Attitudes equals to affective layer which means that the tolerance to different cultures, the deep understanding of own culture and respect to other culture; Behavior equals to behavior layer which means that linguistic competence, nonverbal competence and an ability to deal with the relationship; Knowledge equals to cognitive layer which means that knowledge about economy, religion, politics, geography, customers and values of own country and target country. In China, although many theories have been put forward, there are few empirical studies in senior high school. Thereby, studies regarding the development of ICC in senior high school have been highlighted because all-round individual development also includes the development of ICC.

3. Some Conclusions from the Studies Home and Abroad

Studies at home and abroad shared the common definition and the teaching goal of intercultural communicative competence is concerning about the ability to communicate appropriately. Nevertheless, ICC is a complicated and advanced competence, so it is necessary to plan ICC teaching content more specifically and design proper requirements for different stages of teaching including primary and middle schools. Only can teachers be aware of the importance of ICC, students can be good language users.

\section{SURVEY AND ANALYSIS ON High SCHOOL StUdENTS' ICC}

This paper will adopt some questionnaires to investigate the current situation of the students' ICC; then the paper will analyze the survey to gain some findings for teaching.

Survey

In this survey, 100 students are elected from a key middle school in Z city which is located in Sichuan province. These students are in Grade 11 because they have finished their study in one year and are familiar with the teaching procedure compared with students in Grade 10. These students are divided into 6 groups based on their language proficiency, that is, below 90, then 90-100, 100-110, 110-120,120-130 and then more than 130. The first table is designed like this :( the basic situation of students)

TABLE 1

THE BASIC SITUATIONS OF STUDENTS

\begin{tabular}{|l|l|l|l|}
\hline Category & Options & Frequency & Percent \\
\hline \multirow{3}{*}{ Gender } & Male & 50 & $50 \%$ \\
\hline \multirow{3}{*}{ Major Type } & Female & 50 & $50 \%$ \\
\hline \multirow{3}{*}{ English Proficiency } & Art & 50 & $50 \%$ \\
\cline { 2 - 4 } & Science & 50 & $50 \%$ \\
\cline { 2 - 4 } & Below 90 & 15 & $15 \%$ \\
\cline { 2 - 4 } & $90-100$ & 15 & $20 \%$ \\
\cline { 2 - 4 } & $100-110$ & 20 & $22 \%$ \\
\cline { 2 - 4 } & $110-120$ & 22 & $15 \%$ \\
\cline { 2 - 4 } & $120-130$ & 15 & $13 \%$ \\
\cline { 2 - 4 } & above & 13 & 20 \\
\hline
\end{tabular}

Before opening the ICC related questionnaire, it is interesting to investigate the relationship between intercultural awareness and language competence in that many people believe that students with high language proficiency should be a good leaner with high intercultural awareness. The questionnaire one (Appendix I) is adapted from K. Cushner's Inventory of Cross- Cultural Sensitivity (Cushner 1997) and includes 10 questions to test students' intercultural awareness. During the survey, students are divided into two groups regarding their scores (above 110 and below 110).According to Crushner, the point is divided into these levels: $30-90,91-150,151-210$. The following table is the result: 
TABLE 2

THE RESULT FROM THE SURVEY OF INTERCULTURAL AWARENESS

\begin{tabular}{|l|l|l|}
\hline & Group A( above 110) Numbers & $\begin{array}{l}\text { Group B(below 110) } \\
\text { Numbers }\end{array}$ \\
\hline Low (30-90) & 39 & 38 \\
\hline Medium(91-150) & 7 & 6 \\
\hline High(151-210) & 4 & 6 \\
\hline
\end{tabular}

From the table, here are some findings: 1) both of the two groups are low in the intercultural awareness; two in thirds of them have low points and only of few of them get high points. 2) It is interesting to find that students in Group B still can get high points in the Intercultural Awareness survey. This result indicates that students are weak in intercultural awareness and there is no strong correlation between intercultural awareness and language competence which has been represented by the exam scores. In other words, students at each level are lacking in this awareness which is harmful for their future language learning, so it is urgent to improve students' intercultural awareness in the high school English. The relationship between the intercultural awareness and language competence verifies the truth: the cultivation of intercultural awareness has to be integrated into the whole teaching process.

The next survey will be related to students' intercultural communicative competence, which mainly examines the affective, behavioral and cognitive dimensions of ICC in English learning. Students are required to finish a questionnaire (Appendix II) about three dimensions, and each dimension contains five items to each one. In the cognitive dimension part, the item is merely about general topics: literature in English, mass media of English speaking countries, political situation of these countries along with religions in these countries and so on. This part is mainly about some basic knowledge about English speaking countries and most of them appear in textbooks. In the affective dimension part, the item is usually about speaker's positive attitude to intercultural communication. On the basis of Byram (1997), this dimension includes willingness to have opportunities to open intercultural communication, to tolerate the difference, to understand and respect cultural differences. Therefore, this part involves willingness, openness, and tolerance to intercultural communication. In the behavioral dimension, the item consists of verbal and nonverbal behaviors. Farewells, compliments, and greetings belong to verbal part, while body language and facial expressions are included in non-verbal part. Based on the Wang zhenya (1994), the questionnaire makes some adaptations to meet the reality of Chinese high school students. In the real communicative process, non-behavioral dimension will further clearly explain students' communicative competence so there is an extra questionnaire designed for testing it.

TABLE 3

RESUlTS OF DIMENSION ONE OF ICC

\begin{tabular}{|l|l|l|}
\hline Number & Percentage of Right Answer & Percentage of Wrong Answer \\
\hline 1 & $41 \%$ & $59 \%$ \\
\hline 2 & $70 \%$ & $30 \%$ \\
\hline 3 & $46 \%$ & $54 \%$ \\
\hline 4 & $78 \%$ & $22 \%$ \\
\hline 5 & $44 \%$ & $56 \%$ \\
\hline
\end{tabular}

From the survey, it can be seen that students can't master the basic knowledge well as teachers expected. Although this knowledge appears in the textbook, teachers just mention it as a lead-in background without more deep explanations. After reviewing these surveys, it is an undeniable fact that students are curious about the western culture but they are poor in many aspects including the legends and even idioms in English because they only accept the reading material exercises rather than literature learning.

TABLE 4

RESULTS OF DIMENSION TWO OF ICC

\begin{tabular}{|l|l|l|l|l|l|}
\hline Item & 6 & 7 & 8 & 9 & 10 \\
\hline Mean & 4.2314 & 3.5320 & 4.4023 & 4.4052 & 4.4032 \\
\hline Std. & 1.12756 & 1.19087 & 1.10654 & 1.17632 & 0.08975 \\
\hline
\end{tabular}

From the survey, it is easily to find that students in high school have a positive attitude to intercultural communication and have a certain extent of tolerance to other people from other counties. However, these answers also indicate a problem that students are unfamiliar with foreign values so sometimes they will adopt their own values to judge the context and make an inappropriate judgment. During the intercultural communication, students need to learn more about other cultures and form an objective attitude to foreign culture.

TABLE 5

RESULTS OF DIMENSION THREE OF ICC

\begin{tabular}{|l|l|l|l|l|l|}
\hline Item & 11 & 12 & 13 & 14 & 15 \\
\hline Accuracy & $52 \%$ & $19 \%$ & $34 \%$ & $12 \%$ & $24 \%$ \\
\hline Error & $48 \%$ & $81 \%$ & $66 \%$ & $88 \%$ & $76 \%$ \\
\hline
\end{tabular}

From the survey, it is shown that behavioral dimension is the worst part of students' intercultural communicative 
competence because the error percentage is up to $80 \%$. Here are two reasons accounting for it: one is that students lack the opportunity to practice it in the real context; another one is the influence of Chinese culture. In other words, students prefer to use Chinese communicative strategies to do communications, which need to be altered in the following teaching process.

\section{IMPLiCATIONS FOR THE CULTIVATION OF ICC IN High SCHOOL TEACHING}

From the previous analysis of dimensions of ICC, a major problem arising from the intercultural communicative competence is the indifference to ICC teaching in the high school so it is necessary to strengthen it in the English class. This part will discuss some pedagogical suggestions for improving ICC based on the China's Standards of English Ability. Since the CSE has been promulgated in 2018, more specific requirements are elaborated in the CSE so that the cultivation of intercultural communicative competence has been integrated into each part in the CSE.

\section{A. The Infusion of Cultural Content}

From the survey, one obvious problem is that there is a lack of relevant cultural content in the high school English class. Actually, the CSE clearly points that the reading content for the level of high school students should be comprised of economy, politics and culture of English-speaking countries which lay the foundation for the intercultural communication. In other words, teachers should provide enough cultural content to students other than only to pay attention to grammar or exams because students are often lacking in the substantial study about foreign cultures, which is of no help for intercultural communication. As mentioned in the former part, culture and language is intertwined with each other so language teaching in current class needs to be changed into culture teaching.

In the light of the complicated dimension of culture, teachers should know what to teach at the high school level. Firstly, the very essence of cultural content needs to be closely associated with the interests of students such as: holiday, school life, food, family life, films and so on. Secondly, during the teaching process, teachers need to be attention to the vocabulary part due to the great differences between English words and Chinese words. On one hand, vocabulary is the basic of language understanding; On the other hand, different connotations between these words will lead to a big divergence in the communication. Take red for example; red usually refers to a positive side in Chinese while in English it often means the negative side. In particular, the CSE definitely explains that students should own a decoding ability for vocabulary usage in the target language environment.

\section{B. The Methods of Cultural Infusion}

In order to cultivate the ICC of students, it is very important to adopt proper methods to implement ICC teaching at school. First, students in high school have some different characters in learning different from adults; in addition they cannot have an access to communicating with foreigners face to face so it is necessary to build simulation environment for students to practice. From the survey, it is known to us that the behavioral dimension is weakest part in the intercultural communicative competence so the emphasis of practice will largely improve their competence. Second, teachers in class must change the traditional teaching methods. Besides books, teachers may make full use of the internet, TV and other electronic materials to raise their interest in English and improve their communicative competence. Third, in the instructing process, teachers need to adopt cultural empathy principle. While learning English, teachers need to instruct native culture as well as target culture so that students could do the comparison and understand other cultures in their shoes. In the CSE, one rule of pragmatics requires high school students to understand other culture and could discuss with other people from target culture so the concept of comparison is in badly need in the class.

\section{CONCLUSION}

Intercultural communicative competence can't be built in one day so it needs to be carried through the whole learning process. In the teaching process, teachers must change the traditional concepts and bring the culture instruction into the class. The purpose of the CSE is to train the comprehensive ability of students and instruct students to a full man so owning the intercultural communicative competence is a prerequisite for it. Students in high school are flexible to accept new things so they can quickly master the intercultural communicative competence under the correct guidance.

\section{APPENDiX OnE. Questions ABOUt Your InTERCULTURAL AWARENESS}

In this part, you need to write down your level of agreement with each statement and there are not right or wrong answers. 


\begin{tabular}{|c|c|c|c|}
\hline Item & Statement & $\begin{array}{l}1=\text { strongly disagree } \\
7=\text { strongly agree }\end{array}$ & Your Choice \\
\hline 1 & $\begin{array}{l}\text { I avoid people who are different } \\
\text { from me. }\end{array}$ & 1234567 & \\
\hline 2 & I think people are simply alike. & 1234567 & \\
\hline 3 & $\begin{array}{l}\text { I enjoy studying with people } \\
\text { from different cultures. }\end{array}$ & 1234567 & \\
\hline 4 & $\begin{array}{l}\text { Ifeel uncomfortable when in the } \\
\text { crowd of other people. }\end{array}$ & 1234567 & \\
\hline 5 & I want to live in other culture. & 1234567 & \\
\hline 6 & $\begin{array}{l}\text { I dislike the food from other } \\
\text { cultures. }\end{array}$ & 1234567 & \\
\hline 7 & $\begin{array}{l}\text { I like listening other countries" } \\
\text { music at regular basis. }\end{array}$ & 1234567 & \\
\hline 8 & $\begin{array}{l}\text { It makes me nervous when I } \\
\text { talk with foreigners. }\end{array}$ & 1234567 & \\
\hline 9 & $\begin{array}{l}\text { I can use knife and fork to eat } \\
\text { food. }\end{array}$ & 1234567 & \\
\hline 10 & $\begin{array}{l}\text { I can accept the culturally } \\
\text { marriage. }\end{array}$ & 1234567 & \\
\hline
\end{tabular}

\section{APPENDIX TWO. INTERCULTURAL COMMUNICATIVE COMPETENCE}

In this survey, there are 15 items concerning about your intercultural communicative competence. Please answer it based on your understanding.

1. Which capital belongs to Australia?
A. Melbourne
B. Canberra
C. Sydney Adelaide

2. Which holiday is celebrated both by Americans and British like Chinese Spring Festival?
A. New Year
B. Christmas Day
C. Thanksgiving Day D. Halloween

3. Who raised the black hole theory?
A. Hawking B. Copernicus
C. Newton
D. Galilei

4. Who writes the novel Harry Potter?
A. Mark Twain
B. Hery James
C. J.K.Rowling D. Shakespeare

5. Which one is the Britain News Organization?
A. $\mathrm{BBC}$
B. VOA

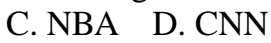

6. If an American student were late for class, he felt very sorry and made apologies to the teacher. I don't think it is necessary.
A. Strongly agree
B. Relatively agree C. Neutral

7. If I asked the age of someone and he refused, I would consider it unfriendly.

$\begin{array}{llll}\text { A. Strongly agree } & \text { B. Relatively agree } & \text { C. Neutral }\end{array}$

8. American old people seldom live with their children. I don't think that they have strong sense of family.
A. Strongly agree
B. Relatively agree
C Neutral
9. I thought the different customs of other countries, such as the kiss in the face is acceptable.
A. Strongly agree
B. Relatively agree
C. Neutral

10. I would like to accept the different cultures and social values.
A. Strongly agree
B. Relatively agree
C. Neutral

11. On the way to school, when students meet professor Tom Smith, students usually say "Good morning, Tom".
A. Appropriate
B. Inappropriate
C. Doubtful

12. Today is cold. When Xiaoming saw Anna was sneezing, he said: "Please wear more clothes".
A. Appropriate
B. Inappropriate
C. Doubtful

13. An American English teacher said to you: "Your English is pretty good." Your response is: "no, no, it's poor.

$\begin{array}{llll}\text { A. Appropriate } & \text { B. Inappropriate } & \text { C. Doubtful }\end{array}$

14. Your English friend gave a birthday gift to you and you unfolded it immediately.
A. Appropriate
B. Inappropriate
C. Doubtful

15. Wang is a secretary in an American company. She worked very hard and the boss said: "Thank you for your contribution." Wang replied like this: "It's my duty."
A. Appropriate
B. Inappropriate
C. Doubtful

\section{APPEndix ThreE. The Third Questionnaire ABout ICC}

In this part, students are required to answer the following ten questions. Each question describes a non-verbal behavior in intercultural communication. Read each question and check whether the underlined part is appropriate and inappropriate.

1. If you want to visit your British friend, you can do it before lunch.

2. If you are invited to a host family while you are abroad, you can bring a bundle of flowers to the hostess. 
3. At a dinner, you can begin to eat when the hostess picks up her spoon.

4. You don't need to give some tip to the girl who shows your seat in the restaurant in the UK.

5. When you feel ill and want to see a doctor, you needn't make an appointment in the U.S.

6 . When you give your hostess a gift, you needn't remove the wrapping paper first.

7. In the English speaking countries, you usually first introduce a man to a woman, not the other way round.

8. You think that Tom is a strange person who usually takes a cold bath.

9. It is more polite to type the letter of invitation than to write them in pen.

10. You needn't stand up when you see a lady come to you.

\section{REFERENCES}

[1] Alptekin, C. (2002). Towards Intercultural Communicative Competence in ELT. ELT Journal, vol.56/1:57-54

[2] Bennett,M.(1986). “A Developmental Approach to Training Intercultural Sensitivity." International Journal of Intercultural Relations. Vol.1:27-69

[3] Byram, M. (1989). Cultural Studies in Foreign Language Education. Clevedon, UK: Multilingual Matters.

[4] Chastain, K. (1976). Developing Second-Language Skills: Theory to Practice. America: Houghton Mifflin.

[5] Chen, G.M \& Starosta, W.J. (1997). A Review of the Concept of Intercultural Sensitivity. Human Communication, vol 3, 1-16.

[6] Cusher, K. (1996). Intercultural Interactions: A Practical Guide. Beverly Hills, CA: Sage Publications.

[7] Freeman, D. (1989). Teachers Training, Development and Decision Making: A Model of Teaching and Related Strategies for Language Teacher Education. TESIL, vol23:27-45

[8] Hall, E. T. (1959). The Silent Language Garden City, New York: Doubleday and Company.

[9] Liitlewood, W. (1981). Communicative Language Teaching. Foreign Language Teaching and Research Press. Shanghai: Foreign Language Education Press.

Lingling Cai was born in Sichuan, China. She received her master degree in European Culture from Sichuan University. She is currently an associate professor in the School of Foreign Languages, Sichuan University of Science and Engineering.

Hong Yun was born in Sichuan, China. She is currently a professor and the dean in the School of Foreign languages, Sichuan University of Science and Engineering. 